\title{
IGFBP2 protects against pulmonary fibrosis through inhibiting P21-mediated senescence
}

Chin Chiahsuan ${ }^{1,2}$, John Lee ${ }^{1,2}$, Ranjith Ravichandran ${ }^{1,2}$, Timothy Fleming ${ }^{1,2}$, Stephen Wheatcroft ${ }^{3}$, Mark Kearney ${ }^{3}$, Ross Bremner ${ }^{1,2}$, Thalachallour Mohanakumar ${ }^{1,2}$, David J Flint ${ }^{4}$, Angara Sureshbabu ${ }^{1,2^{*}}$

${ }^{1}$ Norton Thoracic Institute, St. Joseph's Hospital and Medical Center, Phoenix, Arizona ${ }^{2}$ Creighton University School of Medicine - Pheonix Regional Campus, Phoenix, Arizona

${ }^{3}$ Leeds Institute of Cardiovascular \& Metabolic Medicine, University of Leeds, Leeds, United Kingdom

${ }^{4}$ Strathclyde Institute of Pharmacy \& Biomedical Sciences, University of Strathclyde, Glasgow, United Kingdom

Running title: IGFBP2 reduces lung fibrosis by inhibiting P21

\section{*Correspondence:}

Angara Sureshbabu $\mathrm{PhD}$,

Norton Thoracic Institute,

St. Joseph's Hospital and Medical Center

124 W. Thomas Road, Ste. 100; Phoenix, AZ 85013

Tel: 602.406.8345; Fax: 602.406.8350

Email: suresh.angara@nortonthoracic.org

Conflict of Interest Statement: The authors have declared that no conflict of interest exists. 


\begin{abstract}
Accumulation of senescent cells contributes to age related diseases including idiopathic pulmonary fibrosis (IPF). Insulin-like growth factor binding proteins (IGFBPs) are evolutionarily conserved proteins that play a vital role in many biological processes. Overall, little is known about the functions of IGFBP2 in the epigenetic regulation of cellular senescence and pulmonary fibrosis. Here, we show that $\operatorname{Ig} f b p 2$ expression was significantly downregulated at both mRNA and protein levels in a low-dose bleomycin-induced pulmonary fibrosis model of aged mice. Using the reduced representation of bisulfite sequencing technique, we demonstrated $I g f b p 2$ downregulation is attributed to DNA methylation of $\mathrm{CpG}$ islands in fibrotic lungs of aged mice. Furthermore, Igfbp2 siRNA knockdown increased both P53 and P21 protein levels in mouse lung epithelial cells exposed to hypoxia treatment. Lentiviral mediated expression of $I g f b 2$ decreased P21 protein levels and significantly reduced beta galactosidase activity in mouse lung epithelial cells challenged with a senescent drug (atazanavir) and hypoxia treatments. Using the RT2 Profiler PCR Array, we found that P21, PAI-1, IRF-5 and IRF-7, important regulators of senescence pathway, were significantly downregulated specifically in type-II alveolar epithelial cells (AECs) of aged human-Igfbp2 transgenic mice after bleomycin challenge. Finally, transgenic expression of human-Igfbp2 in type-II AECs from aged bleomycin challenged mice significantly decreased senescent associated secretory phenotype factors and also reduced extracellular matrix markers compared to aged wild-type mice challenged with bleomycin injury. Collectively, these findings reveal that epigenetic repression of $\operatorname{Ig} f b p 2$ promotes pulmonary fibrosis and that restoring IGFBP2 in fibrotic lungs could prove effective in IPF treatment.
\end{abstract}


bioRxiv preprint doi: https://doi.org/10.1101/2021.01.21.427684; this version posted January 22, 2021. The copyright holder for this preprint (which was not certified by peer review) is the author/funder. All rights reserved. No reuse allowed without permission.

KEYWORDS: Aging, Fibrosis, IGFBP2, Lung, Methylation, P21, Senescence, Secretome 


\section{Introduction}

Idiopathic pulmonary fibrosis (IPF) is the most common and severe form of interstitial lung disease affecting more than 5 million individuals worldwide (1). IPF is a heterogeneous disease often occurring in the elderly and there are no effective treatments that can reverse or halt the disease. IPF has a dismal prognosis, with a median survival rate of less than 3 years. Advanced age is a significant risk factor for IPF and yet very little is known about how age contributes to the pathogenesis of IPF (2). Although much of the pathogenesis of IPF remains unclear, alveolar epithelium emerged as a principal site of injury in IPF. This disease is typically characterized with aberrant alveolar epithelium that triggers myofibroblast activation and excessive extracellular matrix deposition (3).

Cellular senescence has recently been implicated as a critical underpinning of age-related fibroproliferative diseases including IPF (4). Cellular senescence, a stress response associated with stable cell cycle arrest is accompanied by the robust secretion of proinflammatory cytokines leading to senescence-associated secretory phenotype (SASP) (5). Growing evidence suggests that P53 and P21 are two key molecular regulators in senescence pathway $(6,7)$ and, accumulation of P21 is typically observed during the process of senescence development (8). Recent studies have demonstrated that selective removal of senescent cells ameliorated a number of age-related diseases $(4,9,10)$. However, the underlying mechanisms of cell senescence in alveolar epithelium remains poorly understood.

The insulin-like growth factor (IGF) system consists of 6 IGF-binding proteins (IGFBPs) with high affinity binding to IGF-I and IGF-II but not insulin (11-13). IGFBPs are ubiquitously expressed in most tissues and their actions are complex and depend upon the tissue and their ability to interact with proteins in the extracellular matrix (14). Although the actions of IGFs are 
modulated by IGFBPs, the cellular functions can also be affected via IGF-independent mechanisms $(15,16)$. IGFBP2 in particular may play an important role in lung function as IGFBP2 levels predicted the risk of a rapid evolution of systemic sclerosis induced interstitial lung disease (17). Growing evidence suggests that IGFBP2 undergoes epigenetic alterations in a tissue specific manner and predicts the development of chronic diseases.(18, 19) Further, IGFBPs play an important role in senescence and aging (20-22). So, we directed our focus on the role of IGFBP2 in epigenetic regulation of cellular senescence specifically in type-II alveolar epithelial cells (AECs) during the pathogenesis of idiopathic pulmonary fibrosis.

In the current study, we investigated whether IGFBP2 regulates cellular senescence and secretion of profibrotic mediators in type-II AECs in the context of idiopathic pulmonary fibrosis. We demonstrated that Igfbp2 expression at both mRNA and protein levels significantly decreased in the lung homogenates of aged mice after low-dose bleomycin challenge. Utilizing gene silencing and overexpression approaches, we show that IGFBP2 inhibits P21 in murine lung alveolar epithelial cells upon hypoxia treatment. Utilizing bleomycin-induced aged pulmonary fibrosis model, we demonstrated that IGFBP2 regulates senescence markers in the type-II AECs of aged IGFBP2 transgenic mice. Finally, we report that transgenic expression of human-Igfbp2 specifically in type-II AECs significantly reduced profibrotic mediators and extracellular matrix markers in response to low-dose bleomycin-induced pulmonary fibrosis in aged mice. These findings may provide new insights for the development of IGFBP-2 targeted therapy that could prove effective for IPF patients. 


\section{Materials and Methods}

\section{Animals}

Aged 18-month-old (78 weeks) C57BL/6J mice were obtained from the Jackson Laboratories (Bar Harbor, Maine, USA). Human-Igfbp2 tamoxifen inducible transgenic mice were obtained from Drs. Kearney and Wheatcroft (Leeds University, United Kingdom). A corresponding Sftpc-cre mouse line was obtained from Jackson Laboratories (Stock \# 028054). Animals were housed under pathogen-free conditions with food and water ad libitum. All experiments and procedures were approved by the Institutional Animal Care and Use Committee at St. Joseph's Hospital and Medical Center (Phoenix, Arizona).

\section{Bleomycin-induced pulmonary fibrosis}

Aged (78 weeks or older) male and female C57BL/6J mice received intratracheal bleomycin (1 U/kg body weight) (Catalog \# 203401; EMD Millipore, Burlington, Massachusetts, USA) or normal saline as previously described (23). To study the molecular signaling of IGFBP2, aged (26 weeks or older) human-Igfbp2 transgenic mice and corresponding wild-type mice received intratracheal instillation of bleomycin $(0.75 \mathrm{U} / \mathrm{kg}$ body weight $)$ or saline. After the instillation, the anesthetized mice were kept on a warm bed for recovery. The experimental animals were monitored daily for adverse clinical signs, including body weight, appearance, hydration status, and any behavioral changes.

\section{Cell culture}

MLE-12 (mouse lung epithelial) cell line was obtained from A.T.C.C. (American Type Culture Collection, Rockville, Maryland, USA), and cultured in DMEM/F12 medium enriched with 2\% fetal bovine serum and $50 \mu \mathrm{g} / \mathrm{ml}$ plasmocin in a humidified atmosphere with $5 \% \mathrm{CO}_{2}$ at $37{ }^{\circ} \mathrm{C}$.

\section{Lentivirus transduction}


Briefly, $1 \times 10^{4}$ cells were mixed with mock or Igfbp2 lentivirus (catalog \# MR204287L3V; OriGene Technologies) at MOI=80 in the $500 \mathrm{ml}$ of $10 \mu \mathrm{g} / \mathrm{ml}$ polybrene/DMEM-F12. The mixture was plated on the $24-w e l l$ plate and centrifuged at $900 \mathrm{~g}$ for 2 hours at $25^{\circ} \mathrm{C}$. After spinfection, the extra $500 \mu \mathrm{l}$ of $2 \% \mathrm{FBS} / \mathrm{DMEM}-\mathrm{F} 12$ were added dropwise onto the cells. The plate was incubated for 48 hours at $37^{\circ} \mathrm{C}$, and replaced the medium to $\%$ FBS/DMEM-F12. $0.5 \mu \mathrm{g} / \mathrm{ml}$ puromycin was used for the selection. The cells were lysed and the IGFBP2 level was estimated by immunoblotting.

\section{Immunoblotting}

Total mice lungs or MLE-12 Cells were lysed by RIPA Lysis Extraction Buffer (catalog \#89901; Thermo Fisher Scientific) along with protease and phosphatase inhibitors cocktail (catalog \#78445; Thermo Fisher Scientific). Total protein concentration was determined by Pierce BCA protein assay reagent kit (catalog \#23227; Thermo Fisher Scientific) according to the manufacturer's protocol. $40 \mu \mathrm{g}$ of total protein was loaded and separated by SDS-polyacrylamide gel electrophoresis. The gel was transferred using a Mini Trans-Blot cell (Biorad) to PVDF membrane (catalog \#IPVH00010; EMD Millipore). Proteins were detected by mouse anti-IGFBP2 (R\&D Systems, catalog \#MAB7971), anti-P21 (Abcam, catalog \#ab188224), anti- $\beta$-actin (catalog \#sc-47778HRP; Santa Cruz Biotechnology) and anti-histone H3 (catalog \#4499; Cell Signaling Technology). Immunoblots were incubated with SuperSignal ${ }^{\mathrm{TM}}$ West Pico or Femto Maximum Sensitivity Substrate (catalog \#34095; Thermo Fisher Scientific).

\section{Statistical Analysis}

All statistical tests were analyzed with the software (GraphPad Prism version 6.0). Statistical analysis was performed using 2-way ANOVA or 1-way ANOVA followed by Tukey's post-hoc 
test. Student's unpaired t-test was used to compare two groups. $P$ value of less than 0.05 was considered statistically significant.

\section{Acknowledgements}

We would like to thank Kristine Nally for proofreading the manuscript.

\section{Financial Statement}

This study did not receive any funding from public or commercial or not-for-profit sources. 


\section{Results}

\section{Low-dose bleomycin induces non-resolving pulmonary fibrosis in aged mice model.}

Intratracheal administration of bleomycin is the most widely used model for studying pulmonary fibrosis in mice. However, several studies have utilized young mice in an attempt to recapitulate features of idiopathic pulmonary fibrosis (IPF). Since IPF is an age-related disease, we administered low-dose intratracheal bleomycin (1U/kg body weight) in an aged (78 weeks old) mice after intubation. Body weight was measured every week and found to be significantly decreased in bleomycin treated compared to normal saline at 7, 14 and 21 days (Fig. 1A). To detect fibrosis, lungs were evaluated for histological evidence; both Sirius Red and Trichrome staining increased after 28 and 50 days, indicating non-resolving fibrosis (Fig. 1B - 1C). The protein levels of collagen-I, fibronectin and vimentin were increased in the lung tissues of aged mice subjected to low-dose intratracheal bleomycin administration. Furthermore, bleomycin treatment decreased Igfbp2 expression at both mRNA and protein levels but increased P21 protein levels (senescence marker), in concomitant with the activation of extracellular matrix (ECM) proteins (Fig. 1D - 1E).

\section{Reduced representation of bisulfite sequencing profiling in aging model of pulmonary fibrosis}

With the findings of decreased Igfbp2 expression at both mRNA and protein levels, regulation is thought to occur at the DNA level. So, we performed global reduced representation bisulfite sequencing in the lung homogenates of aging mice challenged with bleomycin treatment. Bisulfite sequencing analysis revealed Fnip2, Rnuxl, Snx21, Hoxa3 and Bcl as some of the top differentially methylated genes in the aging model of bleomycin-induced pulmonary fibrosis (Fig. $2 \mathrm{~A}-2 \mathrm{~B})$. Interestingly, we also observed significantly increased DNA methylation of Igfbp2 but 
no change in DNA methylation of Cdknla (also known as P21) in aged low-dose bleomycin treated lungs as compared to saline control suggesting a regulatory role for Igfbp2 gene methylation (Fig. $2 \mathrm{C}-2 \mathrm{E})$.

\section{IGFBP2 deficiency elevates senescent markers upon hypoxia treatment}

To assess the biological relevance of IGFBP2, we utilized mouse lung epithelial (MLE-12) cells exposed to $0.1 \%$ hypoxia as an in vitro model of alveolar epithelial injury. The protein levels of P53 and P21 were increased but IGFBP2 protein levels decreased in MLE-12 cells exposed to $0.1 \%$ hypoxia at $4 \mathrm{~h}$ (Fig. 3A). Furthermore, we showed decreased IGFBP2 protein levels in the nuclear fractions of MLE-12 cells challenged with hypoxia as compared to normoxia (Fig. 3B). Furthermore, to evaluate the function of IGFBP2 we performed siRNA transfection in MLE-12 cells challenged with hypoxia treatment. We showed increased P53 and P21 protein levels in MLE12 cells treated with Igfbp2 siRNA compared to non-targeting siRNA and that increase was also observed after 4 h hypoxia treatment (Fig. 3C).

\section{Lentiviral expression of IGFBP2 reduces P21 expression and beta-galactosidase activity}

To determine the action of IGFBP2, we undertook a lentiviral transduction approach in MLE-12 cells exposed to hypoxia treatment. Consistent with the results from Igfbp2 silencing, lentiviral expression of $I g f b p 2$ decreased P21 levels in MLE-12 cells in response to hypoxia treatment when compared with mock virus treated MLE-12 cells exposed to hypoxia (Fig. 4A). Furthermore, both cytosolic and nuclear fractions showed decreased P21 levels in Igfbp2 lentivirus-transduced MLE12 cells in response to hypoxia treatment (Fig. 4B).

Since senescence-associated (SA) $\beta$-galactosidase ( $\beta$-gal) activity is a marker for senescence, we evaluated the endogenous SA- $\beta$-gal function of IGFBP2 in MLE-12 cells exposed to atazanavir 
(protease inhibitor) and hypoxia treatments. Biochemical analysis showed that SA- $\beta$-gal activity significantly increased in MLE-12 cells after 4 days of treatment with atazanavir and hypoxia. Importantly, Igfbp2 expressed through lentivirus transduction significantly decreased SA- $\beta$-gal activity in MLE-12 cells after treatment with atazanavir and hypoxia at $96 \mathrm{~h}$ (Fig. 4C).

\section{Senescence RT2 Profiler PCR Array in type-II alveolar epithelial cells of human-IGFBP2 transgenic mice}

To study the mechanism of IGFBP2 in the development of pulmonary fibrosis, we utilized tamoxifen inducible transgenic ( $\mathrm{Tg}$ ) mice that have the human-Igfbp2 gene knocked into the ROSA26 locus flanked by a floxed STOP codon (Fig. E 1A - 1B). Utilizing RT2 Profiler PCR Array, first we examined the expression of senescence genes in the aged (78 weeks old) lungs of low-dose bleomycin treated wild-type mice. We identified significant upregulation of important senescence genes - Cdkn2a, Cdkn2b, Ifn- $\gamma$, Pai-2, Tp53bpl along with 34 other senescent related genes (Fig. E 2A - 2B). To investigate the effects of Igfbp2, primary type-II AECs were isolated from human-Igfbp2 Tg mice after bleomycin injury. Mouse cellular senescence RT2 Profiler PCR Array was used to analyze the expression of senescence genes specifically in type-II AECs of aged (26 weeks old) human-Igfbp2 Tg mice after 14 days of bleomycin treatment. qPCR array data analysis identified 31 upregulated and 21 downregulated genes relevant to cellular senescence pathway. Primary type-II AECs from aged human-Igfbp2 Tg mice exposed to bleomycin treatment showed downregulation of important senescence genes viz., Cdknla (P21), Pai-1, Irf-5, Irf-7, Tp53bpl as well as fibronectin as compared to aged wild-type mice exposed to bleomycin treatment (Fig. 5). 


\section{Transgenic expression of human-IGFBP2 reduces extracellular matrix deposition and senescence associated secretory phenotype}

We next examined the in vivo effect of human-Igfbp2 transgenic aged mice, 6 months or older, in bleomycin-induced pulmonary fibrosis. To this end, we first assessed bleomycin-induced weight loss at 7 day intervals after intratracheal instillation of bleomycin injury. Human-Igfbp2 transgenic mice were significantly protected from weight loss at days 7, 14 and 21 as relative to aged wildtype mice after bleomycin injury (Fig. 6A). Both Sirius Red and Trichrome staining showed reduced lung fibrosis content in human-Igfbp2 transgenic mice at 28 days as relative to aged WT mice challenged with bleomycin treatment (Fig. 6B). Similarly, compared with aged wild-type mice, human-Igfbp2 transgenic mice showed decreased extracellular matrix markers - Collagen1, Fibronectin and Vimentin in the lungs at 14 days after bleomycin injury (Fig. 6C - 6D). Furthermore, quantitative RT-PCR analysis of type-II AECs from aged human-Igfbp2 mice showed downregulation of SASP factors viz., Il-1 $\beta$, Tnf- $\alpha, M c p-1$, Stat6 and Il-4 compared to aged wild-type mice challenged with bleomycin treatment indicating abrogation of pulmonary fibrosis (Fig. 6E). 


\section{Discussion}

In the present study we provide evidence that IGFBP2 inhibits P21, well established senescence marker, and reduces non-resolving pulmonary fibrosis in aged mice after bleomycin injury. Using type-II AEC specific Sftpc promoter human-Igfbp2 transgenic mice, we are capable of demonstrating reduced senescence, SASP factors, extracellular matrix deposition and improved pulmonary fibrosis in the bleomycin-challenged aged mice.

Cellular senescence, an evolutionarily selected process, counteracts early life cancer (24). Initially, senescence may act as protective response by limiting proliferation but studies have shown that accumulation of senescence is the key pathogenic mechanism that drives the development of pulmonary fibrosis $(4,25)$. Advanced age is the predominant risk factor for age related pathologies and importantly for the development of pulmonary fibrosis (26). Recent studies have utilized aged mice as an improved new model for idiopathic pulmonary fibrosis (27). In line with this, we confirm that challenging aged mice (18 months old), with low-dose bleomycin injury resulted in non-resolving pulmonary fibrosis even after 50 days.

Studies have indicated that senescence is also accompanied by epigenetic and chromatin remodeling of nuclear architecture $(28,29)$. In this study, DNA methylation of Igfbp2 was significantly increased in bleomycin-challenged aged mice but DNA methylation of $C d k n 1 a(\mathrm{P} 21)$ did not change. Consistent with this, recent reports demonstrated upregulation of P21 expression in human lungs with IPF compared to donor lungs $(30,31)$. In contrast, decreased expression of IGFBP2 specifically in fibrotic lungs of aged mice may seem counterintuitive to a recent report showing higher levels of circulating IGFBP1 and IGFBP2 in the serum of IPF patients (32). However, the elevated serum levels of IGFBP2 in IPF patients may be reasoned due to aberrant secretion by immune cells eliciting an immune response and is a subject of further investigation. 
Another possible explanation is that the relationship of Igfbp2 DNA methylation in lungs and circulating IGFBP2 levels are largely independent i.e., heterogenous cell-types involved and functional roles of IGFBP2 acting downstream of IPF.

Alveolar epithelial cell senescence is evident in IPF and in a variety of experimental models of lung fibrosis (30). P53 plays a central role in cellular senescence mainly through P21 induction. In this study, we show that silencing Igfbp2 in mouse lung epithelial cells increased both P53 and P21 protein levels in response to hypoxia treatment. Similarly, lentiviral mediated expression of Igfbp2 decreased P21 protein levels and also reduced SA- $\beta$-galactosidase activity in response to atazanavir and hypoxia treatments. There is considerable evidence that IGFBP2 is detected in the nuclei and such nuclear translocation is mediated by a functional nuclear localization signal sequence (33). In relevance to this, we show that IGFBP2 protein levels were upregulated in the nuclear fraction as relative to the cytosolic fraction in MLE-12 cells exposed to hypoxia treatment.

Previous studies have shown that type-II AECs undergo senescence and secrete profibrotic mediators in bleomycin-induced pulmonary fibrosis (34). In this study, we systematically examined senescence markers in type-II AECs obtained from human-Igfbp2 transgenic mice. We show downregulation of senescent markers - Cdknla, encoding P21, Pai-1, Irf-5, Irf-7 and Tp53bpl in aged human-Igfbp2 transgenic mice as compared to aged wild-type mice challenged with bleomycin treatment. In agreement with this, a recent report showed interferon regulated genes - IRF-5 and IRF-7 induce senescence in immortal fibroblasts (35). Another report showed increased P53BP1 positive foci in the development of radiation-induced lung injury (36). Importantly, emerging evidence suggests that DNA damage-induced P21 expression increasing to stable levels allows the cell to permanently exit the cell cycle and undergo senescence or apoptosis $(6,37)$. In addition to senescence related genes, we investigated the expression of SASP in type-II 
AECs overexpressing human-Igfbp2 after bleomycin-induced lung injury. Specifically, we show significant downregulation of established SASP components - Tnf- $\alpha, I l-1 \beta$, Mcp-1 and Stat6. Although Il-4 was upregulated, recent reports suggest that IL-4 plays a dichotomous role in pulmonary fibrosis $(38,39)$. Nevertheless, we demonstrated that IGFBP2 regulates both P21 levels and profibrotic mediators in bleomycin-challenged aged mice suggesting that IGFBP2 acts as an upstream regulator of P21-mediated senescence. Furthermore, we show reduced protein levels of ECM markers in the lungs of human-Igfbp2 transgenic mice compared to aged WT mice challenged with bleomycin exposure. These data support the concept that restoring IGFBP2 levels in the fibrotic lungs may have beneficial effect for IPF patients.

In summary, we showed that IGFBP2 inhibits P21-mediated senescence at least in type-II AECs and also reduces SASP components in aged mice subjected to bleomycin-induced lung injury and fibrosis. These results suggest that transgenic expression of human-Igfbp2 specifically in type-II AECs reduces non-resolving pulmonary fibrosis by inhibiting senescence as well as profibrotic mediators. 


\section{REFERENCES}

1. Meltzer EB, Noble PW. Idiopathic pulmonary fibrosis. Orphanet J Rare Dis. 2008;3:8.

2. Janssens JP, Pache JC, Nicod LP. Physiological changes in respiratory function associated with ageing. Eur Respir J. 1999;13(1):197-205.

3. Katzenstein AL. Pathogenesis of "fibrosis" in interstitial pneumonia: an electron microscopic study. Hum Pathol. 1985;16(10):1015-24.

4. Schafer MJ, White TA, Iijima K, Haak AJ, Ligresti G, Atkinson EJ, Oberg AL, Birch J, Salmonowicz H, Zhu Y, Mazula DL, Brooks RW, Fuhrmann-Stroissnigg H, Pirtskhalava T, Prakash YS, Tchkonia T, Robbins PD, Aubry MC, Passos JF, Kirkland JL, Tschumperlin DJ, Kita H, LeBrasseur NK. Cellular senescence mediates fibrotic pulmonary disease. Nat Commun. $2017 ; 8: 14532$.

5. He S, Sharpless NE. Senescence in Health and Disease. Cell. 2017;169(6):1000-1011.

6. Galanos P, Vougas K, Walter D, Polyzos A, Maya-Mendoza A, Haagensen EJ, Kokkalis A, Roumelioti FM, Gagos S, Tzetis M, Canovas B, Igea A, Ahuja AK, Zellweger R, Havaki S, Kanavakis E, Kletsas D, Roninson IB, Garbis SD, Lopes M, Nebreda A, Thanos D, Blow JJ, Townsend P, Sørensen CS, Bartek J, Gorgoulis VG. Chronic p53-independent p21 expression causes genomic instability by deregulating replication licensing. Nat Cell Biol. 2016;18(7):77789.

7. Yosef R, Pilpel N, Papismadov N, Gal H, Ovadya Y, Vadai E, Miller S, Porat Z, Ben-Dor S, Krizhanovsky V. p21 maintains senescent cell viability under persistent DNA damage response by restraining JNK and caspase signaling. Embo j. 2017;36(15):2280-2295.

8. Campisi J, d'Adda di Fagagna F. Cellular senescence: when bad things happen to good cells. Nat Rev Mol Cell Biol. 2007;8(9):729-40.

9. Ogrodnik M, Miwa S, Tchkonia T, Tiniakos D, Wilson CL, Lahat A, Day CP, Burt A, Palmer A, Anstee QM, Grellscheid SN, Hoeijmakers JHJ, Barnhoorn S, Mann DA, Bird TG, Vermeij WP, Kirkland JL, Passos JF, von Zglinicki T, Jurk D. Cellular senescence drives agedependent hepatic steatosis. Nat Commun. 2017;8:15691.

10. Luo C, Zhou S, Zhou Z, Liu Y, Yang L, Liu J, Zhang Y, Li H, Liu Y, Hou FF, Zhou L. Wnt9a Promotes Renal Fibrosis by Accelerating Cellular Senescence in Tubular Epithelial Cells. J Am Soc Nephrol. 2018;29(4):1238-1256.

11. Allard JB, Duan C. IGF-Binding Proteins: Why Do They Exist and Why Are There So Many? Front Endocrinol (Lausanne). 2018;9:117.

12. Sureshbabu A, Tonner E, Flint DJ. Insulin-like growth factor binding proteins and mammary gland development. Int J Dev Biol. 2011;55(7-9):781-9. 
13. Ewald CY, Landis JN, Porter Abate J, Murphy CT, Blackwell TK. Dauer-independent insulin/IGF-1-signalling implicates collagen remodelling in longevity. Nature. 2015;519(7541):97-101.

14. Bach LA. IGF-binding proteins. J Mol Endocrinol. 2018;61(1):T11-t28.

15. Frommer KW, Reichenmiller K, Schutt BS, Hoeflich A, Ranke MB, Dodt G, Elmlinger MW. IGF-independent effects of IGFBP-2 on the human breast cancer cell line Hs578T. J Mol Endocrinol. 2006;37(1):13-23.

16. Sureshbabu A, Okajima H, Yamanaka D, Tonner E, Shastri S, Maycock J, Szymanowska M, Shand J, Takahashi S, Beattie J, Allan G, Flint D. IGFBP5 induces cell adhesion, increases cell survival and inhibits cell migration in MCF-7 human breast cancer cells. J Cell Sci. 2012;125(Pt 7):1693-705.

17. Gester F, Henket M, Deseny D, Moermans C, André B, Malaise M, Louis R, Guiot J. IGFBP-2: a new pathway in systemic sclerosis associated interstitial lung disease. European Respiratory Journal. 2019;54(suppl 63):OA3597.

18. Kammel A, Saussenthaler S, Jähnert M, Jonas W, Stirm L, Hoeflich A, Staiger H, Fritsche A, Häring HU, Joost HG, Schürmann A, Schwenk RW. Early hypermethylation of hepatic Igfbp2 results in its reduced expression preceding fatty liver in mice. Hum Mol Genet. 2016;25(12):2588-2599.

19. Wittenbecher C, Ouni M, Kuxhaus O, Jähnert M, Gottmann P, Teichmann A, Meidtner K, Kriebel J, Grallert H, Pischon T, Boeing H, Schulze MB, Schürmann A. Insulin-Like Growth Factor Binding Protein 2 (IGFBP-2) and the Risk of Developing Type 2 Diabetes. Diabetes. 2019;68(1):188-197.

20. Byun HO, Lee YK, Kim JM, Yoon G. From cell senescence to age-related diseases: differential mechanisms of action of senescence-associated secretory phenotypes. BMB Rep. 2015;48(10):549-58.

21. Kim KS, Kim MS, Seu YB, Chung HY, Kim JH, Kim JR. Regulation of replicative senescence by insulin-like growth factor-binding protein 3 in human umbilical vein endothelial cells. Aging Cell. 2007;6(4):535-45.

22. Kim KS, Seu YB, Baek SH, Kim MJ, Kim KJ, Kim JH, Kim JR. Induction of cellular senescence by insulin-like growth factor binding protein-5 through a p53-dependent mechanism. Mol Biol Cell. 2007;18(11):4543-52.

23. Helms MN, Torres-Gonzalez E, Goodson P, Rojas M. Direct tracheal instillation of solutes into mouse lung. J Vis Exp. 2010;(42)

24. Campisi J. Aging, cellular senescence, and cancer. Annu Rev Physiol. 2013;75:685-705. 
25. Rana T, Jiang C, Liu G, Miyata T, Antony V, Thannickal VJ, Liu RM. PAI-1 Regulation of TGF- $\beta 1$-induced Alveolar Type II Cell Senescence, SASP Secretion, and SASP-mediated Activation of Alveolar Macrophages. Am J Respir Cell Mol Biol. 2020;62(3):319-330.

26. Meiners S, Eickelberg O, Königshoff M. Hallmarks of the ageing lung. Eur Respir J. 2015;45(3):807-27.

27. Hohmann MS, Habiel DM, Coelho AL, Verri WA, Jr., Hogaboam CM. Quercetin Enhances Ligand-induced Apoptosis in Senescent Idiopathic Pulmonary Fibrosis Fibroblasts and Reduces Lung Fibrosis In Vivo. Am J Respir Cell Mol Biol. 2019;60(1):28-40.

28. Tzouvelekis A, Kaminski N. Epigenetics in idiopathic pulmonary fibrosis. Biochem Cell Biol. 2015;93(2):159-70.

29. Rani A, Chin C, Bremner R, Mohanakumar T, Angara S. Targeting chromatin dysregulation in organ fibrosis. Cytokine Growth Factor Rev. 2020;

30. Lehmann M, Korfei M, Mutze K, Klee S, Skronska-Wasek W, Alsafadi HN, Ota C, Costa R, Schiller HB, Lindner M, Wagner DE, Günther A, Königshoff M. Senolytic drugs target alveolar epithelial cell function and attenuate experimental lung fibrosis ex vivo. Eur Respir J. 2017;50(2)

31. Okuda R, Aoshiba K, Matsushima H, Ogura T, Okudela K, Ohashi K. Cellular senescence and senescence-associated secretory phenotype: comparison of idiopathic pulmonary fibrosis, connective tissue disease-associated interstitial lung disease, and chronic obstructive pulmonary disease. J Thorac Dis. 2019;11(3):857-864.

32. Guiot J, Bondue B, Henket M, Corhay JL, Louis R. Raised serum levels of IGFBP-1 and IGFBP-2 in idiopathic pulmonary fibrosis. BMC Pulm Med. 2016;16(1):86.

33. Azar WJ, Zivkovic S, Werther GA, Russo VC. IGFBP-2 nuclear translocation is mediated by a functional NLS sequence and is essential for its pro-tumorigenic actions in cancer cells. Oncogene. 2014;33(5):578-88.

34. Jiang C, Liu G, Luckhardt T, Antony V, Zhou Y, Carter AB, Thannickal VJ, Liu RM. Serpine 1 induces alveolar type II cell senescence through activating p53-p21-Rb pathway in fibrotic lung disease. Aging Cell. 2017;16(5):1114-1124.

35. Li Q, Tang L, Roberts PC, Kraniak JM, Fridman AL, Kulaeva OI, Tehrani OS, Tainsky MA. Interferon regulatory factors IRF5 and IRF7 inhibit growth and induce senescence in immortal Li-Fraumeni fibroblasts. Mol Cancer Res. 2008;6(5):770-84.

36. Beach TA, Groves AM, Johnston CJ, Williams JP, Finkelstein JN. Recurrent DNA damage is associated with persistent injury in progressive radiation-induced pulmonary fibrosis. Int J Radiat Biol. 2018;94(12):1104-1115. 
37. Feringa FM, Raaijmakers JA, Hadders MA, Vaarting C, Macurek L, Heitink L, Krenning L, Medema RH. Persistent repair intermediates induce senescence. Nat Commun. 2018;9(1):3923.

38. Huaux F, Liu T, McGarry B, Ullenbruch M, Phan SH. Dual roles of IL-4 in lung injury and fibrosis. J Immunol. 2003;170(4):2083-92.

39. Izbicki G, Or R, Christensen TG, Segel MJ, Fine A, Goldstein RH, Breuer R. Bleomycininduced lung fibrosis in IL-4-overexpressing and knockout mice. Am J Physiol Lung Cell Mol Physiol. 2002;283(5):L1110-6. 
bioRxiv preprint doi: https://doi.org/10.1101/2021.01.21.427684; this version posted January 22, 2021. The copyright holder for this preprint (which was not certified by peer review) is the author/funder. All rights reserved. No reuse allowed without permission.

\section{Figures}

\section{Figure 1}

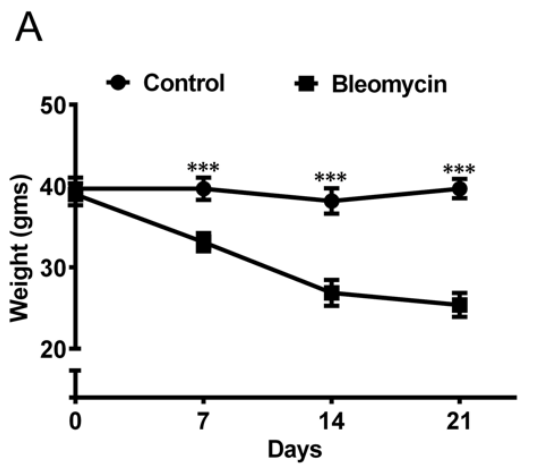

C

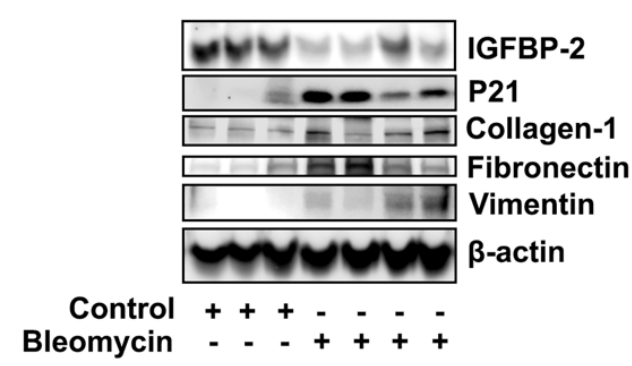

B
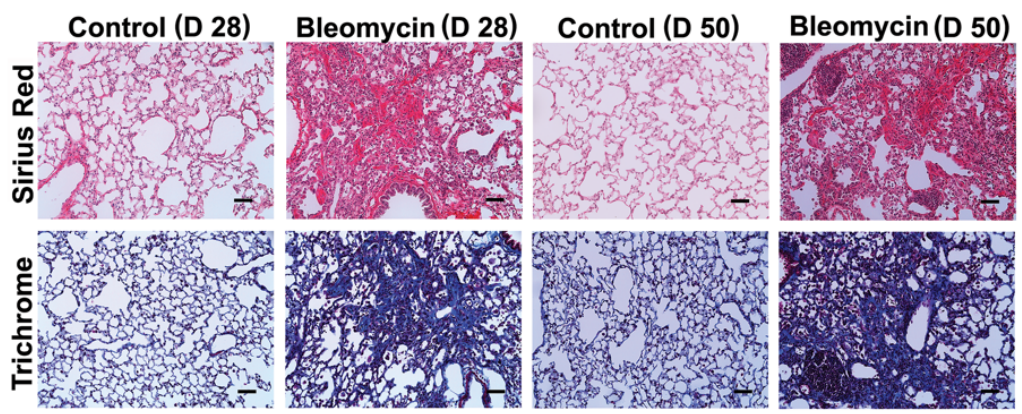

D

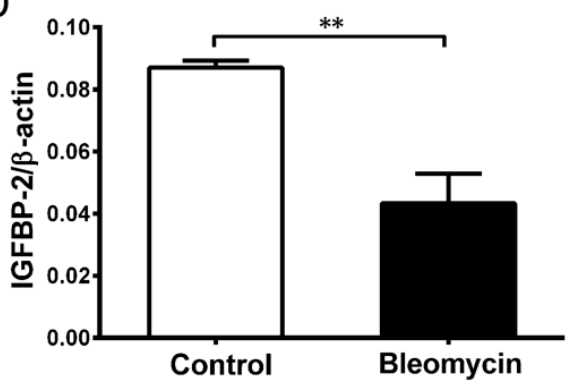


bioRxiv preprint doi: https://doi.org/10.1101/2021.01.21.427684; this version posted January 22, 2021. The copyright holder for this preprint (which was not certified by peer review) is the author/funder. All rights reserved. No reuse allowed without permission.

\section{Figure 2}

A

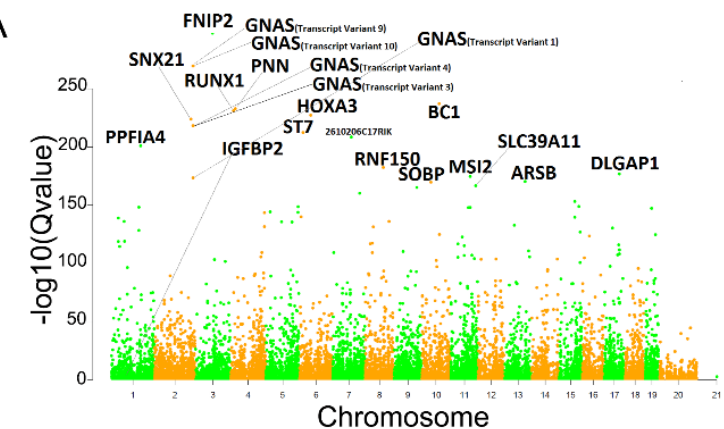

C

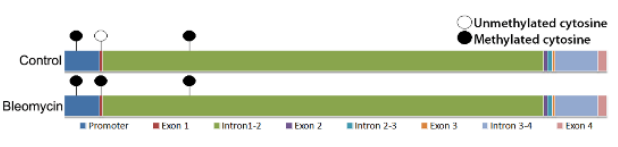

D

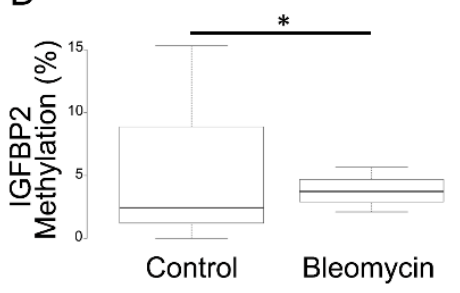

B

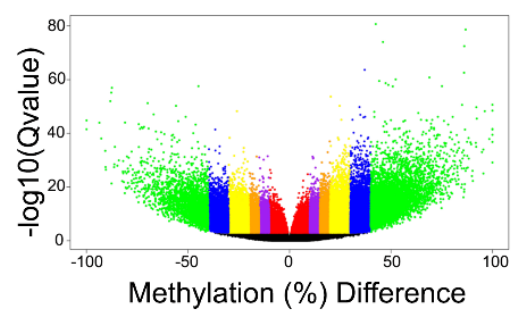

E

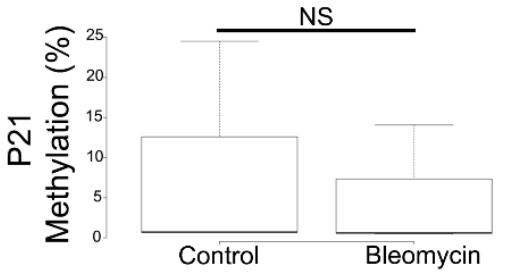




\section{Figure 3}

A

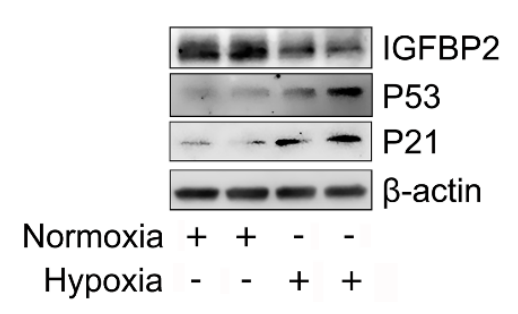

B

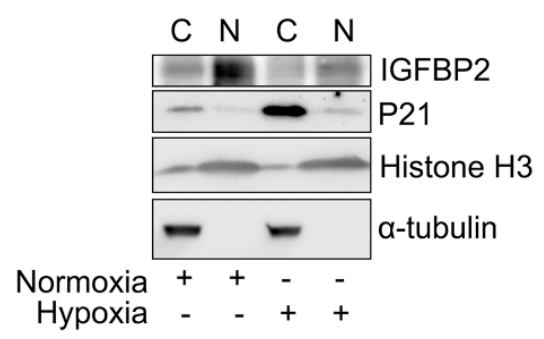

C

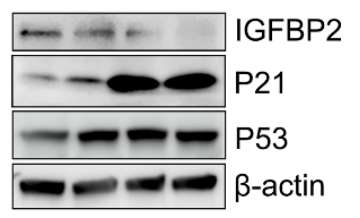

NT SiRNA + + - -

IGFBP2 SiRNA - -++

Hypoxia - +-+ 
bioRxiv preprint doi: https://doi.org/10.1101/2021.01.21.427684; this version posted January 22, 2021. The copyright holder for this preprint (which was not certified by peer review) is the author/funder. All rights reserved. No reuse allowed without permission.

Figure 4

A

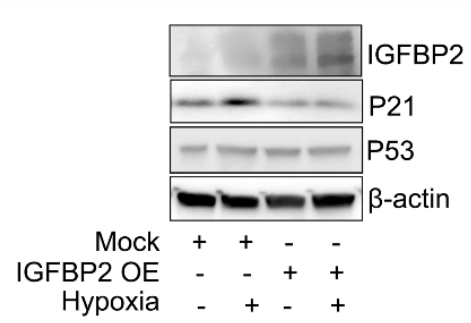

B

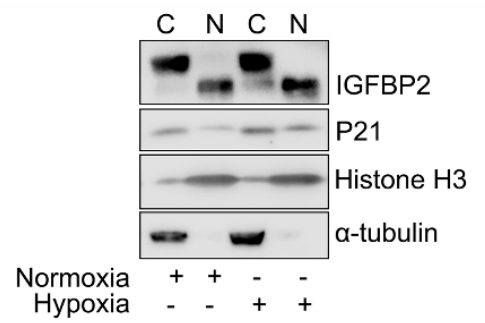

C

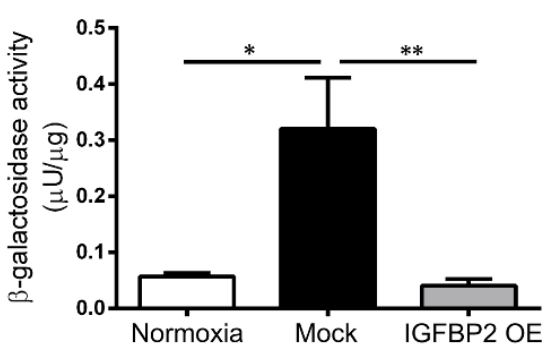


bioRxiv preprint doi: https://doi.org/10.1101/2021.01.21.427684; this version posted January 22, 2021. The copyright holder for this preprint (which was not certified by peer review) is the author/funder. All rights reserved. No reuse allowed without permission.

\section{Figure 5}

A

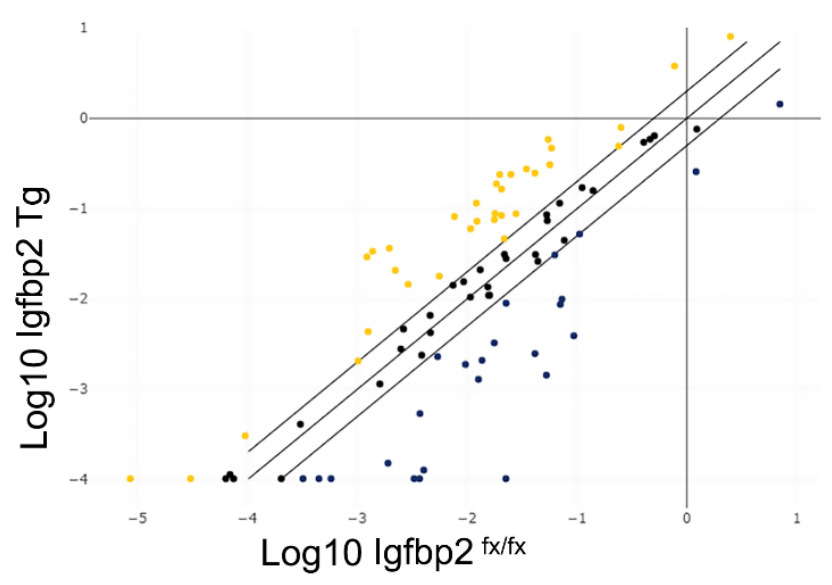

B

\begin{tabular}{|l|l|}
\hline Gene Symbol & Up Regulation \\
\hline Aldh1a3 & 11.95 \\
\hline Atm & 2.03 \\
\hline Bmi1 & 9.47 \\
\hline Calr & 4.91 \\
\hline Ccna2 & 12.04 \\
\hline Ccnb1 & 10.67 \\
\hline Ccnd1 & 4.92 \\
\hline Ccne1 & 4.99 \\
\hline Cdc25c & 18.62 \\
\hline Cdk2 & 4.28 \\
\hline Cdk6 & 2.12 \\
\hline Cdkn1b & 7.98 \\
\hline Cdkn2a & 23.83 \\
\hline Cdkn2b & 24.44 \\
\hline Chek1 & 3.47 \\
\hline Cited2 & 3.15 \\
\hline Creg1 & 3.15 \\
\hline Gsk3b & 9.57 \\
\hline Igfb33 & 3.38 \\
\hline Irf3 & 4.10 \\
\hline Map2k6 & 9.36 \\
\hline Mdm2 & 7.92 \\
\hline Nbn & 3.20 \\
\hline Pik3ca & 5.89 \\
\hline Pten & 10.67 \\
\hline Rb1 & 10.17 \\
\hline Rb11 & 8.03 \\
\hline Sod1 & 5.98 \\
\hline Sod2 & 5.41 \\
\hline Tert & 3.21 \\
\hline Tgfb1 & 2.05 \\
\hline Trp53 & 5.57 \\
\hline & \\
\hline
\end{tabular}

\begin{tabular}{|l|l|}
\hline Gene Symbol & Down Regulation \\
\hline Akt1 & -23.85 \\
\hline Cdkn1a & -8.09 \\
\hline Chek2 & -4.36 \\
\hline E2f1 & -12.49 \\
\hline Fn1 & -4.72 \\
\hline Gadd45a & -5.12 \\
\hline Ifng & -2.34 \\
\hline Igf1r & -32.05 \\
\hline Igfbp5 & -3.12 \\
\hline Igfbp7 & -35.92 \\
\hline Ing1 & -6.51 \\
\hline If5 & -36.66 \\
\hline Irf7 & -219.06 \\
\hline Map2k1 & -2.04 \\
\hline Pcna & -2.02 \\
\hline Plau & -5.41 \\
\hline Prkcd & -7.34 \\
\hline Rb12 & -9.83 \\
\hline Serpine1 & -2.52 \\
\hline Sparc & -31.43 \\
\hline Tgfb1i1 & -5.62 \\
\hline Thbs1 & -16.66 \\
\hline Trp53bp1 & -6.90 \\
\hline & \\
\hline
\end{tabular}


bioRxiv preprint doi: https://doi.org/10.1101/2021.01.21.427684; this version posted January 22, 2021. The copyright holder for this preprint (which was not certified by peer review) is the author/funder. All rights reserved. No reuse allowed without permission.

\section{Figure 6}

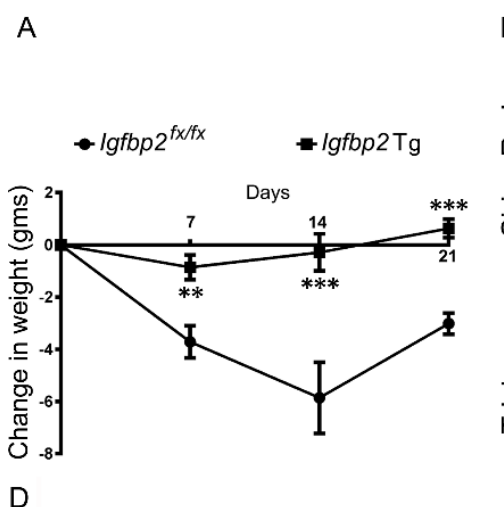

B

$\operatorname{lgfbp} 2^{\mathrm{fx} / \mathrm{fx}}$

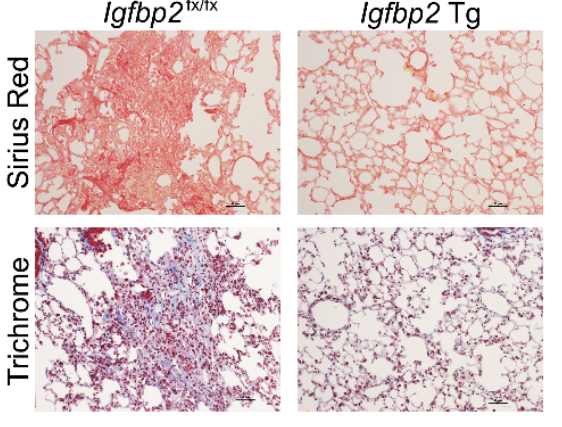

C

E

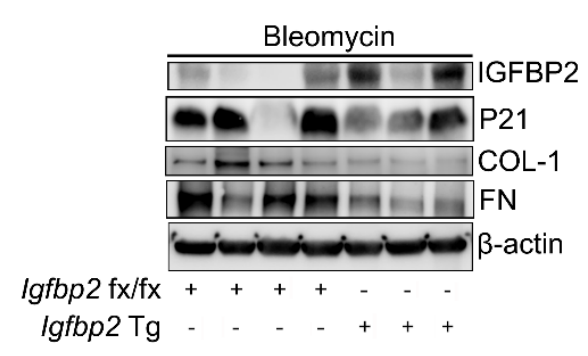

$\operatorname{lgfbp} 2 \mathrm{fx} / \mathrm{fx} \quad \operatorname{lgfbp} 2 \mathrm{Tg}$

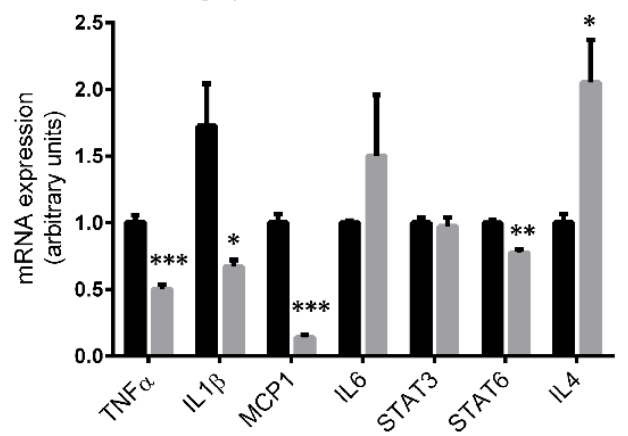

lgfbp2 Tg - - +++ 


\section{Legends}

Figure 1. Low-dose bleomycin induces irreversible pulmonary fibrosis in aged mice. (A) Line plot showing body weights of aged (78 weeks old) wild-type (WT; C57BL/6J) mice 7, 14 and 21 days after intratracheal administration of normal saline (equal volume) or bleomycin (1U/kg body weight). ( $\mathrm{n}=8$ WT saline; $\mathrm{n}=8$ WT bleomycin). (B-C) Sirius Red or Mason's Trichrome stained lung sections of aged mice 28 or 50 days after intratracheal administration of bleomycin. Scale bars: $50 \mu \mathrm{m}$. ( $\mathrm{n}=6 \mathrm{WT}$ saline; $\mathrm{n}=8 \mathrm{WT}$ bleomycin) (D) Western blot for expression of IGFBP2, P21, Collagen-I, Fibronectin and Vimentin in the lung homogenates of aged mice 14 days after low-dose bleomycin challenge. Beta-actin is used as the internal control. $(n=6$ WT saline; $n=8$ WT bleomycin). (E) IGFBP2 mRNA expression in the lung homogenates of aged mice subjected to low-dose bleomycin challenge after 14 days. ( $n=6$ WT saline; $n=6$ WT bleomycin). Data are mean \pm SEM of 3 independent experiments. $* * * \mathrm{P}<0.001$, two-way ANOVA $* * \mathrm{P}<0.01$ Student's unpaired t-test.

Figure 2. Reduced Representation of Bisulfite Sequencing of low-dose bleomycin induced pulmonary fibrosis in aged mice. (A) Manhattan plot showing the top 20 differentially methylated genes and IGFBP2 gene for all the chromosomes. The red line indicates the significant level of Qvalue $<0.01$. (B) Volcano plot showing the methylation (\%) difference in all genes. (C) Lollipop plot showing the methylated cytosine regions of IGFBP2 promoter, exons and introns. (D) Box plot showing the significantly increased differentially methylation region of $I g f b p 2$ variant (NM_001310659.1) in low-dose bleomycin-induced pulmonary fibrosis mice. (E) Box plot showing no change of differentially methylated region of Cdknla in low-dose bleomycin-induced 
pulmonary fibrosis mice. ( $\mathrm{n}=3 \mathrm{WT}$ saline; $\mathrm{n}=3 \mathrm{WT}$ bleomycin) $* \mathrm{P}<0.05$ Student's unpaired ttest.

Figure 3. IGFBP2 deficiency increases $\mathrm{P} 21$ expression in response to hypoxia stimulus (A) Western blot for the expression of IGFBP2, P53, P21 in MLE-12 cells exposed to absence or presence of hypoxia treatment. (B) Western blot for the expression of IGFBP2 and P21 in the cytosolic and nuclear fractions of MLE-12 cells that were exposed to absence or presence of hypoxia treatment. Alpha-tubulin and histone-3 served as internal controls (C) Non-targeting or Igfbp2 siRNA transduced MLE-12 cells were exposed to absence or presence of hypoxia treatment. Western blot for the expression of IGFBP2, P53 and P21. Beta-actin served as internal control. Data are representative of minimum of 3 independent experiments.

Figure 4. Stable transduction with Igfbp2 lentivirus vector decreased P21 expression and betagalactosidase activity (A) Mock virus and Igfbp2 lentivirus-transduced MLE-12 cells in the absence or presence of hypoxia treatment. Western blot for the expression of IGFBP2, P21 and P53. Beta-actin served as internal control (B) Western blot for the expression of IGFBP2 and P21 in the cytosolic and nuclear fractions of Igfbp2 lentivirus-transduced MLE-12 cells in the absence or presence of hypoxia treatment. (C) Bar graph showing the beta galactosidase activity of MLE12 cells treated with Atazanavir and hypoxia for 96 h. Data are representative of minimum of 3 independent experiments. 
Figure 5. Cellular senescence gene profiling in type-II alveolar epithelial cells of aged humanIgfbp2 transgenic mice (A) Scatter plot showing the upregulated and downregulated genes relevant to senescence pathway in isolated type-II AECs from aged (26 weeks old) human-Igfbp2 transgenic mice after 14 days of low-dose bleomycin treatment $(0.75 \mathrm{U} / \mathrm{kg}$ body weight). Yellow dots indicate upregulated genes; black dots indicate no change; blue dots indicate downregulated genes. (B) Table showing the list of fold regulated genes with gene symbol. + indicates upregulated genes; - indicates downregulated genes. (n = $3 \operatorname{Igfbp} 2 \mathrm{fx} / \mathrm{fx} ; \mathrm{n}=3 \operatorname{Igfbp} 2 \mathrm{Tg})$

Figure 6. Effects of aged human-Igfbp2 transgenic mice challenged with bleomycin treatment. (A) Line plot showing the change in body weights of aged (26 weeks) wild-type and human-Igfbp2 transgenic mice subjected to intratracheal administration of bleomycin treatment $(0.75 \mathrm{U} / \mathrm{kg}$ bodyweight). ( $\mathrm{n}=7 \operatorname{Igfbp} 2 \mathrm{fx} / \mathrm{fx} ; \mathrm{n}=7 \operatorname{Igfbp} 2 \mathrm{Tg}) . * * * \mathrm{P}<0.001$ and $* * \mathrm{P}<0.01$, two-way ANOVA (B) Sirius Red or Mason's Trichrome stained lung sections of aged wild-type and humanIgfbp2 transgenic mice 28 days after intratracheal administration of bleomycin treatment. Scale bars: $50 \mu \mathrm{m} .(\mathrm{n}=4 \operatorname{Igfbp} 2 \mathrm{fx} / \mathrm{fx} ; \mathrm{n}=3 \operatorname{Igfbp} 2 \mathrm{Tg})$. (C-D) Western blot for the expression of Collagen-I, Fibronectin, P21 and Vimentin. (n = $4 \operatorname{Igfbp} 2 \mathrm{fx} / \mathrm{fx} ; \mathrm{n}=3 \operatorname{Igfbp} 2 \mathrm{Tg}$ ). (E) RT-PCR analysis for mRNA expression of TNF- $\alpha$, IL-1 $\beta$, MCP-1, IL-6, STAT3, STAT6 and IL-4 in aged wild-type and human-Igfbp2 transgenic mice 14 days after intratracheal administration of bleomycin. $(\mathrm{n}=4 \operatorname{Igfbp} 2 \mathrm{fx} / \mathrm{fx} ; \mathrm{n}=3 \operatorname{Igfbp} 2 \mathrm{Tg}) . * * * \mathrm{P}<0.001, * * \mathrm{P}<0.01$ and $* \mathrm{P}<0.05$ Student's unpaired t-test. 
Online Data Supplement

IGFBP2 protects against pulmonary fibrosis through inhibiting P21-mediated senescence

Chin Chiahsuan, John Lee, Ranjith Ravichandran, Timothy Fleming, Stephen Wheatcroft, Mark

Kearney, Ross Bremner, Thalachallour Mohanakumar, David J Flint, Angara Sureshbabu 


\section{Methods}

\section{Hypoxia treatment}

Approximately $16 \mathrm{~h}$ before the exposure to hypoxia, $1 \times 10^{6} \mathrm{MLE}-12$ were seeded on to the $10 \mathrm{~cm}$ dish. Subsequently, MLE-12 cells were transferred to the incubation chamber with $0.1 \% \mathrm{O}_{2}$ and $5 \%$ of $\mathrm{CO}_{2}$ for the different time points exposure. After hypoxia treatment, cells were prepared for downstream experiments.

\section{Generation of SFTPC-cre-ERT2-human-Igfbp2 transgenic mice}

Sftpc (surfactant protein C)-cre hIgfbp2 $2^{\text {flox }}$ (human Igfbp2 knocked into the ROSA26 locus flanked by a floxed STOP codon) was generated by crossing a mouse line expressing tamoxifen-inducible cre under control of the type II alveolar epithelial cell-specific promoter Sftpc with human$\operatorname{Igfbp} 2^{\text {flox }}$. The genotype of transgenic mice was confirmed by PCR with the following primers:

182053 Cre1: 5'- CTCCCAAAGTCGCTCTGAGTTGTTATCA - 3'

182054 Cre2: 5'- CGATTTGTGGTGTATGTAACTAATCTGTCTGG-3'

0034-Kin-ROSA-GX6044: 5' - GCAGTGAGAAGAGTACCACCATGAGTCC-3’

13007-mutant reverse: 5'-ACACCGGCCTTATTCCAAG-3'

24999-common: 5'-TGCTTCACAGGGTCGGTAG-3'

25000-Wild type reverse: 5'- TGCTTCACAGGGTCGGTAG-3'

The band was at 245 bp for the homozygous of Igfbp2, and 210 bp for the Sftpc-cre driven mice. To induce the Cre expression, mice were injected via i.p. with 5 doses of tamoxifen every other day for $0.45 \mathrm{mg} / \mathrm{kg}$ body weight. 


\section{Reduced representation of bisulfite sequencing analysis}

Total lung DNA from aged (78 weeks old) wild-type mice challenged with bleomycin (1U/kg body weight) treatment were extracted using DNeasy Blood \& Tissue kit (catalog \# 69504, Qiagen). DNA concentration was assessed using Nanodrop and only samples with optical density A260/A280 $\geqq 1.8$ were chosen. Reduced Representation of Bisulfite Sequencing (RRBS) was performed on a RRBS service basis by the company Diagenode (Diagenode Inc, catalog \# G02020000). The comparisons between the saline (control) and bleomycin treatment RRBS datasets were carried out using R package GeneDMR (1). RefGene database mm10 and CpG island annotation from the UCSC genome browser (http://genome.ucsc.edu) were used. Differentially methylated regions (DMRs) were annotated using the UCSC Refseq tracks (mm10) to further analyze $\mathrm{CpG}$ sites included in genes - promoter regions, introns and exons upstream and downstream of transcriptional start site.

\section{Cytosolic/ nuclear protein fractionation}

$1.0 \times 10^{7}$ MLE- 12 cells in the $10 \mathrm{~cm}$ dish were exposed to the hypoxia condition for 4 and 24 hours, respectively. Cells were harvested, and resuspended with 1x cytosolic extraction buffer (10 mM HEPES, $1.5 \mathrm{mM} \mathrm{MgCl2,} 10 \mathrm{mM} \mathrm{KCl,} 0.05 \% \mathrm{NP} 40 \mathrm{pH}$ 7.9). Then, cells were incubated on ice for 10 mins, and lysed with $25 \mu 1$ Thermo Scientific ${ }^{\mathrm{TM}}$ RIPA Lysis and Extraction Buffer (Thermo Fisher Scientific, catalog \#89901) with protease and phosphatase inhibitor cocktails (Fisher Scientific, catalog \#78445). The supernatant was collected after centrifugation for 10 mins at 800xg. The pellet was washed twice with 1x cytosolic extraction buffer. The pellet was lysed with 
$50 \mu 1$ Thermo Scientific ${ }^{\mathrm{TM}}$ RIPA Lysis and Extraction Buffer and incubated on ice for 30 minutes by vortexing for 5-minute intervals. The nuclear fraction was collected from the supernatant after the centrifugation for 30 minutes at $14,000 \mathrm{xg}$. The cytosolic/nuclear fraction was detected by immunoblotting assay.

\section{$\beta$-galactosidase activity assay}

MLE-12 cells were seeded at $8 \times 10^{5}$ cells per $10 \mathrm{~cm}$ dish at $37^{\circ} \mathrm{C}$ for overnight, and $20 \mu \mathrm{M}$ atazanavir (Sigma-Aldrich, catalog \#SML1796-5MG) was added two times at $24 \mathrm{~h}$ intervals. Simultaneously, MLE-12 cells were incubated in hypoxia $(0.1 \%)$ for $96 \mathrm{~h}$. Endogenous $\beta$ galactosidase activity was measured by the $\beta$-Gal Activity Assay Kit (BioVision, catalog\# K821100). Briefly, MLE-12 cells were lysed using $100 \mu \mathrm{l}$ ice cold $\beta$-Gal assay buffer for 15 min after atazanavir and hypoxia treatments for $96 \mathrm{~h}$. Supernatant was collected after centrifugation at $10,000 \mathrm{X} \mathrm{g}$ for $10 \mathrm{~min}$ at $4^{\circ} \mathrm{C}$. About $10 \mu \mathrm{l}$ of supernatant was used along with $\beta$-Gal substrate and fluorescence was measured using Spectramax i3 fluorometer (Molecular Devices, Inc.) in kinetic mode for $5-60 \mathrm{~min}$ at $37^{\circ} \mathrm{C}$.

\section{Primary type II alveolar epithelial cell isolation}

The Sftpc-Cre-ERT2-human-IGFBP2 $2^{\text {flox }}$ transgenic mice and corresponding wild-type mice were sacrificed after 14 days of bleomycin $(0.75 \mathrm{U} / \mathrm{kg}$ body weight $)$ treatment, and the lung was perfused with $30 \mathrm{ml}$ of saline to remove the blood. Lungs collected from the same condition mice were minced into $1 \mathrm{~mm}$ pieces and digested with the mixture of $1 \mathrm{mg} / \mathrm{ml}$ of collagenase I and 5 $\mathrm{U} / \mathrm{ml}$ of Dispase at $37^{\circ} \mathrm{C}$ for 25 minutes. Cells were passed through a $400 \mu \mathrm{m}$ filter and neutralized 
by equal volume of $20 \%$ FBS. Cells were centrifuged at 180xg and resuspended by $10 \%$ FBS with DMEM/F12. First, suspended cells were separated by CD45 MACS cell separation magnetic beads (catalog \# 130-052-301, Miltenyi Biotec), and CD45 depletion cells were collected. CD45- cells were sequentially separated by EpCAM magnetic beads (catalog \#130-105-958, Miltenyi Biotec). The column was washed three times with $3 \mathrm{ml}$ of PBS containing 0.5\% Bovine serum albumin (catalog \#A30075, RPI Research), and EpCAM positive cells were collected after removing the column from the magnetic separator (catalog \#130-091-051, Miltenyi Biotec) and flushing the column with $0.5 \%$ bovine serum albumin in the saline. CD45-/EpCAM+ cells were further filtered with a $30 \mu \mathrm{m}$ filter and the total RNA was extracted from the cells by all prep DNA/RNA mini kit (catalog \#80204, Qiagen).

\section{Senescence gene expression profiling}

Cellular senescence gene expression profiling was performed using $\mathrm{RT}^{2}$ Profiler PCR Array (catalog \#330231, Qiagen). AEC2 cells were isolated from the lungs of normal saline or bleomycin treated mice. RNA was extracted as per the manufacturer instructions described in $\mathrm{RT}^{2}$ first strand kit (catalog \#330401, Qiagen). cDNA was combined with RT² SYBR Green qPCR Master Mix (catalog \#330520, Qiagen), and $\Delta \Delta \mathrm{CT}$ was measured by StepOnePlus ${ }^{\mathrm{TM}}$ Real-Time PCR System (catalog \#4376600, Thermo Fisher Scientific). The further analysis and fold regulation were calculated based on the $\triangle \Delta C T$ method using the GeneGlobe data analysis web portal (www.qiagen.com/geneglobe). The primers for senescence associated secretory phenotype (SASP) genes were obtained from RealTime Primers (\# OS1, realtime primers.com). The list of primer sequences for the quantitative PCR for the SASP genes are below: 
Table E1: Mouse primer sequences for qPCR

\begin{tabular}{|ll|}
\hline Gene Name & \multicolumn{1}{c|}{ Primer sequences } \\
\hline IL-1 $\beta$ & $\begin{array}{l}\text { F-primer: 5'- GCAACTGTTCCTGAACTCAACT-3' } \\
\text { R-primer: 5'-ATCTTTTGGGGTCCGTCAACT-3' }\end{array}$ \\
\hline IL-4 & $\begin{array}{l}\text { F-primer: 5'- GGTCTCAACCCCCAGCTAGT '3' } \\
\text { R-primer: 5' - GCCGATGATCTCTCTCAAGTGAT-3' }\end{array}$ \\
\hline IL-6 & F-primer: 5'-TAGTCCTTCC-3' \\
& R-primer: 5'-TACCCCAATTTCC-3' \\
\hline MCP-1 & F-primer: 5'- TTAAAAACCTGGATCGGAACCAA-3' \\
& R-primer: 5' - GCATTAGCTTCAGATTTACGGGT-3' \\
\hline STAT3 & F-primer: 5'- CAATACCATTGACCTGCCGAT-3' \\
& R-primer: 5'- GAGCGACTCAAACTGCCCT-3' \\
\hline STAT6 & F-primer: 5'- CTCTGTGGGGCCTAATTTCCA-3' \\
& R-primer: 5'- CATCTGAACCGACCAGGAACT-3' \\
\hline TNF- $\alpha$ & F-primer: 5'- CCCTCACACTCAGATCATCTTCT-3' \\
& R-primer: 5' - GCTACGACGTGGGCTACAG \\
\hline
\end{tabular}


Figure Legends

Figure E1. Agarose gel electrophoresis showing the genotyping of Igfbp2 transgenic mice obtained through crossing the Igfbp2 flox with Sftpc-cre mice. (A) Sequence of the PCR amplified regions encompassing wild-type, heterozygote and mutant genotypes for Sftpc-cre. Mutant, 327 bp; Heterozygous, 210 and 327 bp; wild-type, 327 bp (B) Sequence of the PCR amplified regions encompassing wild-type, heterozygote and mutant genotypes for Igfbp2 flox. Mutant, 245 bp; Heterozygous, 245 and 778 bp; wild-type, 778 bp.

Figure E2. (A) Scatter plot showing the RT2 Profiler PCR Array for 84 genes related to cellular senescence pathways performed in the lungs of aged wild-type mice subjected to low-dose bleomycin injury. Red dots indicates upregulated genes; black dots indicate no change; blue dots indicate downregulated genes. (B) Table showing the list of fold upregulated and down regulated genes in the total lungs challenged with bleomycin as compared to normal saline $(n=3$ saline control; $\mathrm{n}=3$ bleomycin). 
bioRxiv preprint doi: https://doi.org/10.1101/2021.01.21.427684; this version posted January 22, 2021. The copyright holder for this preprint (which was not certified by peer review) is the author/funder. All rights reserved. No reuse allowed without permission.

\section{Supplementary Figures}

Figure E1

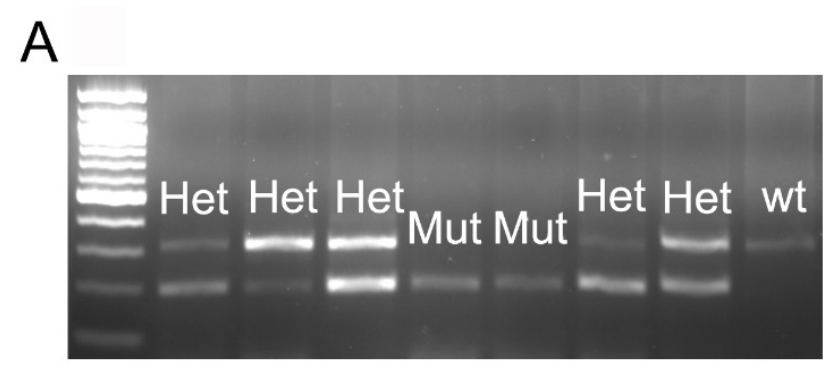

B

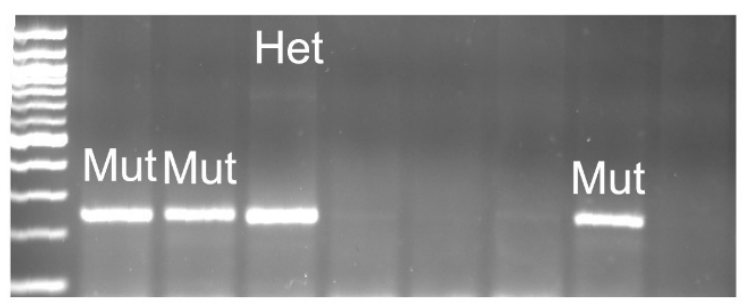


bioRxiv preprint doi: https://doi.org/10.1101/2021.01.21.427684; this version posted January 22, 2021. The copyright holder for this preprint (which was not certified by peer review) is the author/funder. All rights reserved. No reuse allowed without permission.

\section{Figure E2}

A

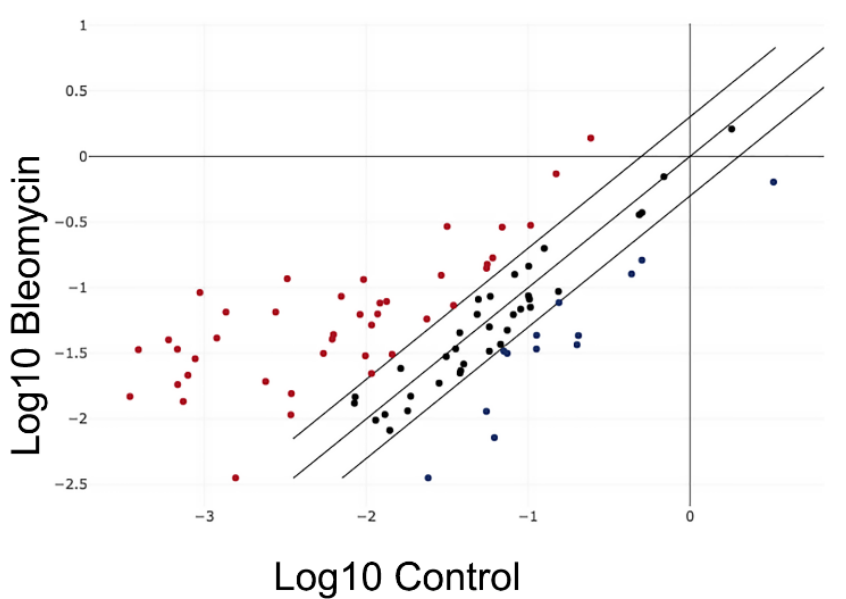

B

\begin{tabular}{|l|l|}
\hline Gene Symbol & Upregulation \\
\hline ABL1 & 12.00 \\
\hline ALDH1A3 & 66.70 \\
\hline ATM & 2.28 \\
\hline CCNA2 & 5.80 \\
\hline CCNB1 & 34.64 \\
\hline CCNE1 & 47.93 \\
\hline CDC25C & 86.17 \\
\hline CDK2 & 2.06 \\
\hline CDK4 & 4.19 \\
\hline CDKN2A & 26.72 \\
\hline CDKN2B & 9.28 \\
\hline CHEK1 & 27.21 \\
\hline CHEK2 & 18.37 \\
\hline COL1A1 & 2.89 \\
\hline COL3A1 & 4.95 \\
\hline E2F1 & 36.05 \\
\hline E2F3 & 4.53 \\
\hline GLB1 & 6.58 \\
\hline GSK3B & 2.79 \\
\hline HRAS & 2.70 \\
\hline IFNG & 42.76 \\
\hline IGF1 & 12.25 \\
\hline IGF1R & 2.54 \\
\hline IRF5 & 4.81 \\
\hline IRF7 & 3.06 \\
\hline MAP2K6 & 3.14 \\
\hline MYC & 23.64 \\
\hline PLAU & 8.07 \\
\hline PRKCD & 2.12 \\
\hline RB1 & 2.44 \\
\hline RBL1 & 5.36 \\
\hline RBL2 & 2.15 \\
\hline SERPINB2 & 32.77 \\
\hline TBX3 & 7.01 \\
\hline TERF2 & 6.28 \\
\hline TERT & 97.93 \\
\hline TP53 & 6.83 \\
\hline TP53BP1 & 5.87 \\
\hline TWIST1 & 49.83 \\
\hline & \\
\hline
\end{tabular}

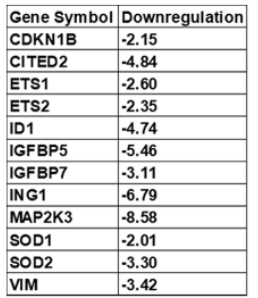


bioRxiv preprint doi: https://doi.org/10.1101/2021.01.21.427684; this version posted January 22, 2021. The copyright holder for this preprint (which was not certified by peer review) is the author/funder. All rights reserved. No reuse allowed without permission.

\section{References}

1. Wang X, Hao D, Kadarmideen HN. GeneDMRs: An R Package for Gene-Based Differentially Methylated Regions Analysis. J Comput Biol. 2020 